\title{
PERSPECTIVE MANAGEMENT: SYSTEMIC THINKING AND VALUE SYNERGY NECESSITY
}

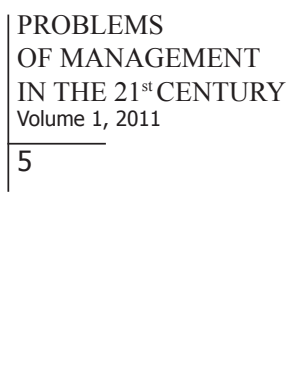

PROBLEMS

Volume 1, 2011

\author{
Vincentas Lamanauskas \\ University of Siauliai, Lithuania \\ E-mail: v.lamanauskas@ef.su.It
}

We can surely assert that over the last two decades a very significant attention has been paid to management. It is great that more and more attention is paid to the systemic approach in management (Robinson, 1996; Jackson, 2003; Bellinger, 2004; Cyrus, 2010). It is obvious, that there are many approaches to management, for example, problem solving style, situational approach, effective steering etc. And not only to management, but also to adjacent, management related spheres. Systemic approach is reasonably considered to be as cornerstone to management. On the one hand, this is bound to common systemic society life changes. Such topics as knowledge economy, learning society, information society and so on... are constantly accentuated. On the other hand, in some countries management as a science was basically "beyond the boundaries" of cognition. First of all, this can be said about East and Central Europe countries, in other words, still called post-soviet countries up to now. Though, the latter term is neither true nor full of sense in many respects. Not without a reason, in the public discourse of these countries the opinion is still vital that the manager is the one who is hardly able to do a thing himself. Even quite practically we can analyse a simple example. Social science field study programmes "have been in the leading position" in Lithuanian higher education for almost two decades already. It is interesting, that in many cases, fewer difficulties in studying, is pointed out as the main motive.

Rapid, quite often controversial social, economic, demographic and other changes are going on in the whole world. In many social life spheres a qualitatively different management strategy is inevitably necessary. How does it reveal itself? First of all, that win those who are able to foresee, assess the future and finally to model it. In other words, always there were and there will always be those who will work only with "burning" problems. How to find a suitable balance? There can't be all first and leaders only, can there? The role of management is undoubtedly weighty. However, world is diverse. Management science is diverse too. Generally we can assert, that at least two management models (of the school) exist-East and West. What is specific to some, it is not necessarily suitable for the others. The necessity of a resultful dialogue arises among various management schools at different levels - both practical and theoretical. It is necessary to share knowledge, experience and practice with others. Real practice component is a very significant one. A phenomenon, to occupy leading positions in the organisation not according to possessed managerial competences, but according to other supposed loyalty criteria is still characteristic to so-called post soviet countries. This is especially distinct in state sector. We can observe conditionally similar situations in educational sector as well, especially in higher education. Isn't it paradoxical, that management knowledge is conveyed to students by the lecturers who themselves have never taken part in the real management process, not having managerial practice and so on.

The aim of this editorial is not to discuss modern management problems. We seek to draw everybody's attention only to several aspects. Management theory and practice can't be separated from other cognition and activity spheres. The manager acting effectively is not only 
PROBLEMS

OF MANAGEMENT

IN THE $21^{\text {st }}$ CENTURY

Volume 1,2011

a good expert in management theories and natural phenomena. It is necessary for him to have proper psychology, sociology and other field knowledge. Management component of value becomes even more important. Various economic crises which from time to time are rolling through the world quite often are determined not by economic-managerial phenomena, but by so-called human factor. This factor quite often reveals itself in the selfishness of certain groups of people, dishonesty, irresponsibility and so on. Thus, possessed managerial experience and abilities do not conform to essential managerial ethics requirements. Moreover, we should talk about social responsibility of the leaders in a wider context. The basis of it is just formed of possessed values - in general sense, human's convictions about "what is good and what is bad". We can orientate into maximum profit of the organisation, not overstepping (and very often on the contrary) legal limits. However, one can behave otherwise - try to coordinate the attempt for profit with altruism. This is a complex, many efforts requiring job. So far, not every manager is able to go along that road and orientate their team into this. Why? First of all, we can think so, because traditional leadership doesn't suit here, traditional perception of it. The future leader is not the one who only ensures sufficient organisation activity efficiency or achieves good financial indicators. The leader is the one who has in himself creative, paradoxical or even risky approaches and is able to show them to others. This is, in fact, another level of leadership. Individual leader's status or personal charismas are not the essential leadership components. A more global, dynamic, softer leadership perception is necessary.

We can agree with Gary Hamel (2007), that today more than ever, organisations need brave management innovations. Modern management model orientated to control and productivity doesn't suit in the world where business success is determined by adjustment and creativity.

Thus, it is believed that discussions on these mentioned and not mentioned management questions will go on in these journal pages. One thing is obvious, that values become one of the most significant and perspective instruments of management effectiveness and optimisation. Value institutionalisation in the organisations is one of the most important guarantors of their effective activity.

\section{References}

Bellinger, G. (2004). Management \& Leadership: A Systemic Perspective. Available on the Internet: http://www.systems-thinking.org/malasp/malasp.htm (accessed on 03/06/2011).

Cyrus, A. (2010). A Systemic Approach to Human Resources Management. Advances in Management, Vol. 3, Issue 5, p. 16-19.

Hamel, G. (2007). The Future of Management. Harvard: Harvard Business School Press.

Jackson, M.C. (2003), Creative Holism for Managers, Kluwer/Plenum, London.

Robinson, W. W. (1996). A systems approach to management. Engineering Management Journal, Vol. 6, Issue 4, p.172-176.

Received: May 20, 2011

Accepted: June 04, 2011

Vincentas Lamanauskas

Professor, Siauliai University, Natural Science Education Research Centre, 25-119 P.Višinskio Street, LT- 76351, Siauliai, Lithuania.

Phone: +37068795668.

E-mail: lamanauskas@projektas.It

Website: http://www.lamanauskas.projektas.It 